\title{
Kerk en burgerlike owerheid: Die Nederlandse geloofsbelydenis en drie kerkordes
}

Author:
Piet J. Strauss ${ }^{1}$
Affiliation:
'Department of Historical
and Constructive Theology,
Faculty of Theology,
University of the Free State,
Bloemfontein, South Africa
Corresponding author:
Piet J. Strauss,
straussp@ufs.ac.za
Dates:
Received: 07 July 2020
Accepted: 13 Oct. 2020
Published: 18 May 2021
How to cite this article:
Strauss, P.J., 2021, 'Kerk
en burgerlike owerheid:
Die Nederlandse
geloofsbelydenis en drie
kerkordes', HTS Teologiese
Studies/Theological Studies
77(4), a6237. https://doi.
mobile device
to read online.
org/10.4102/hts.v77i4.6237
Copyright:
Q 2021. The Authors.
Licensee: AOSIS. This work
is licensed under the
Creative Commons
Attribution License.

Church and state authorithy: The Confessio Belgica and three church orders. In reformed churches the Bible is regarded as the norm of the norms. The confessions of faith of these churches are the second norm and subjected to the Bible. The church order is less powerful than the Bible and the confessions but of a higher status than the normal decisions of church assemblies. Therefore, the influence of the Belgic Confession on three church orders is an important issue in these churches.

The author recommends four principles to understand the relation between the church and the state authority in article 36 of the Belgic Confession: both should honour God in their activities; both are guided by the Ten Commandments; both have their own internal law to fulfil the purpose as an institution; and both should respect and co-operate with one another. Although they are not in agreement on every aspect, these principles give the guidance to understand the main issue in all four documents which are investigated. The theme of this article is of a theological and church historical nature and a contribution on a well-discussed topic in reformed churches.

Contribution: It should be important for the reformed churches in the Dutch tradition that a dynamic relationship exists between their confessions of faith and their church orders. While the Bible is the first and most important norm for church life, the confessions are the second most important. Church history shows that the relationship between the church and state is of utmost importance for the church, the quality of the confessions and the order of the church.

Keywords: Bible norm of norms or norma normans; Confessio Belgica norma normata; State uses their power to proclaim Word of God - Confessio Belgica; Church order of Dordt determines approach of church to Christian authority; Church order of Reformed Churches and Dutch Reformed Church work with state. Bybel norm van die norme of norma normans; Nederlandse Geloofsbelydenis norma normata; Staat en staatsapparaat vir verkondiging van die Woord - volgens Nederlandse Geloofsbelydenis; Dordtse Kerkorde artikel 28 reël optrede van kerk teenoor Christelike owerheid; Gereformeerde en Ned. Geref. Kerkorde werk met staat in algemeen.

\section{Inleidend}

In sommige gereformeerde kerke word dit aanvaar dat hulle belydenisskrifte oor kern- of essensiële waarhede van die Christelike geloof handel. ${ }^{1}$ Waarhede wat so duidelik Skriftuurlik is dat dit gelowiges oortuig, hulle dit uit die hart bely en dit deur meer kerke aanvaar word. Kernwaarhede van die geloof wat eenheidsvormend op gelowiges en kerkeinwerk. Gemeenskaplik aanvaarde waarhede wat die geestelike eenheid van die betrokke kerke as geloofsinstellings formuleer én uitsê. ${ }^{2}$

Die Nederlandse Geloofsbelydenis (NGB) as deel van die Drie Formuliere van Eenheid of 'n uitdrukking van gereformeerdes se geloofseenheid, is saam met die ander twee by die Sinode van Dordrecht van 1618-1619 as belydenisse aanvaar. Marthinus Gregorii, 'n kommissaris-politiek by die vergadering, glo dat dit vir hierdie sinode by die aanvaarding van die Drie Formuliere om die 'essentia doctrinae' (essensie van die leer) van die Bybels-Christelike geloof gegaan het en nie

1.Jonker (1994) glo dat belydenisskrifte ' $n$ 'samevatting van die essensiële inhoud van die Christelike geloof gee' (p. 6). Vroeër wys Bouwman daarop dat gereformeerdes gedurende die ontstaanstyd van die Nederlandse Geloofsbelydenis in 1561 'van harte' ingestem het met die 'eeuwige waarheden' wat daarin bely word en hulle bereid verklaar het om hierdie waarhede met hulle 'bloed te bezegelen', 'n pad wat die opsteller, Guido de Brès, op 31 Mei 1567 met 'n galgdood in die openbaar sou loop (Bouwman 1985:568; Oosthuizen 2008:210; S.A. Strauss 2008c:789). Die Nederlandse Geloofsbelydenis (1561) is die eerste van die Drie Formuliere van Eenheid wat op 30 April 1619 en later deur die Nasionale (ekumeniese) Sinode van Dordtrecht as ' $n$ uitdrukking van sy geloofseenheid aanvaar is (Donner \& Van den Hoorn s.a.:307vv, 320). Na die NGB in 1561 kom die Heidelbergse Kategismus van 1563 (S.A. Strauss 2008b:436),
en die Dordtse Leerreëls van 1619 (S.A. Strauss 2008a:250).

2. Heyns beweer dat ' $n$ belydenis nie die 'ganse openbaringsinhoud' van die Bybel wil 'omvat' nie, maar kernwaarhede van die Skrif weergee. ' $n$ Belydenis is nie net ' $n$ gevoelsopwelling nie, maar' $n$ verwoording van die kern van die geloof as ' $n$ persoonlike saak met gemeenskaplike implikasies. Die ware kerk moét bely, nie omdat die kerk'n belydenis het nie, maar omdat die belydenis die kerk hét (Heyns 1977:159; 1992:17). 
soseer die 'phraseologie of methode' daarvan nie (Donner \& Van den Hoorn s.a.:325). ${ }^{3}$ Kuyper (s.a.) verwys na hierdie Sinode met die 'eerenaam' van die eerste gereformeerde ekumeniese sinode in die geskiedenis (p. vi). 'n Sinode wat rondom die leerstellige deel van sy agenda uit afgevaardigdes van gereformeerde kerke in Nederland, Engeland, Duitsland en Switserland bestaan het en as 'n ekumeniese vergadering die Drie Formuliere aanvaar het. Die Drie Formuliere wat rondom die destydse strydvraag van die Reformasie met die Rooms-Katolieke Kerk, op die leer van die verlossing konsentreer. 'n Genadige verlossing uit Gods hand wat in die Formuliere geïntegreer word met die antwoord op die vraag na God drie-enig deur die vroeë kerk: juis omdat Dordt sy eenheid met die 'heilige, algemene Christelike kerk' wou handhaaf en uitdruk. Die Reformasie wou nie 'n sektariese afskeiding van die Roomse Kerk wees nie, maar 'n voortsetting van die heilige, algemene Christelike kerk (Jonker 1994:6, 19, 49). Daarby word drie ekumeniese belydenisskrifte uit die vroeë kerk naamlik die Apostolicum, Nicea en Athanasius wat aldrie oor God drie-ening handel, ook in NGB artikel 9 opgeneem. Dit hoef dus nie afsonderlik aanvaar te word nie (NG Kerk-Uitgewers 1982:14).

Heyns (1992:395) noem dit merkwaardig of selfs vreemd dat die NGB, nadat hy dit oor die kerk en die sakramente as kernaspekte van die Christelike geloof gehad het, aan die kerk in sy verhouding met die burgerlike owerheid aandag gee. Hyself wys egter op twee redes hiervoor.

Eerstens praat die Bybel oor die saak sodat die NGB wat 'n sistematiese vertolking van Skrifwaarhede wou gee, dit kwalik kon ignoreer. Tweedens was die konkrete omstandighede van die Reformasie met die ontstaan van die NGB van so 'n aard dat dit van kernbelang vir sy voortbestaan as kerk was om oor die verhouding kerk-staatsowerheid uitsluitsel te kry (Heyns 1992:395). In hierdie tyd - en later - moes die kerk helder wees oor sy verhouding met die owerheid wat met die dwingende mag van die swaard in ' $n$ bepaalde gebied 'nie verniet nie' (Rom 13:4) regeer. ' $n$ Owerheid wat daar is deur die beskikking of voorsienigheid van God òf 'n de facto-owerheid wat deur God beskik en so 'n de iure of wettige Romeine 13-owerheid is. ${ }^{5}$ Wettig omdat hy oor sy staatsgebied regeer met sy monopolie oor die fisiese swaardmag of beheer in daardie gebied soos deur die God beskik (Strauss 2010:128-129). ${ }^{6}$

3. Die Sinode van die Christian Reformed Church of North America van 1976 verklaar dat die Skriftur in weid vansings, sinspelings en toevallige of 'incidental' opmerkings daarin gaan nie, maar 'th doctrines which are confessed' (Engelhard \& Hofman 2001:50-51). Calvyn handhaa die onderskeid tussen essensiële of hoofsake en middelmatige sake van die geloo Volgens hom hoef verskille oor laasgenoemde nie die eenheid van die kerk te bedreig nie, terwyl eersgenoemde soos in belydenisskrifte vervat die belyde akkoord of ooreenkoms van kerklike gemeenskap is (Sizoo s.a.:21).

4.Fowler noem die staat ' $n$ dominante faktor in 'n moderne samelewing. 'No programme of action in modern society can ignore the state' (Fowler 1988:16). Kleynhans (1988) oordeel dat die verhouding kerk-staat 'n kernpunt in die kerkgeskiedenis bly omdat dit die kerk knel as dinge hier skeefloop (p. 190).

5.Calvyn beskou die instelling van die staat na die sondeval as ' $n$ ordinansie van God (Sizoo s.a.:555). Hy noem die kerk die siel en die staat die liggaam van die menslike samelewing (Sizoo s.a.:559). Saam vorm hul ' $n$ eenheid of twee kante van die gemeenskap: Calvyn se idee van die samelewing as ' $n$ teokratiese verbondsgemeenskap.

6.Van Niekerk (1987:11vv.) en Degenaar (1996:9) gaan lynreg teenoor hierdie stelling gegrond op Romeine 13:1-7 in as hulle humanisties indiwidualisties en demokratisties aanvoer dat' $n$ wettige regering gebaseer moet wees op die steun en instemming van die meerderheid van die bevolking.
Omdat die NGB artikel 36 kernaspekte van die norme of beginsels vir die verhouding van die kerk en die burgerlike owerheid bely en dit nie net verklaar of sê nie, is dit vir kerke wat die NGB aanvaar naas die Bybel die tweede norm vir kerk, kerkordes én Skrif-, belydenis- en kerkordegebonde besluite (in hierdie gesagsvolgorde) van kerkvergaderings. Daarom, omdat NGB artikel 36 kernsapekte van die verhouding kerk-staatsowerheid bely, dra dit kerklik meer gesag as die gewone besluite en verklarings van kerkvergaderings. En omdat kerkordes wat meer duursaam as gewone besluite van sinodes moet wees én, onderhewig aan die Skrif as die norma normans (eerste norm) en die belydenis as die norma normata (hieraan ondergeskikte tweede norm), self normatief vir die besluite van die betrokke kerk is (Celliers 2003:307-312; Heyns 1992:39), is die band tussen NGB artikel 36 en die drie gereformeerde Kerkordes wat hier ondersoek word, uit die oogpunt van gereformeerde kerke belangrik (vgl. NGKO-2015:1, 12, 13 \& artikel 1, 44-47).

Gevolglik kyk hierdie artikel na die kernaspekte van die verhouding van kerk en burgerlike owerheid in NGB artikel 36 en die invloed daarvan op drie kerkordes: die Dordtse Kerkorde van 1619 (DKO-1619 in Pont 1981:176-186) en die Kerkordes van die Gereformeerde Kerke in Suid-Afrika (GKSAKO-2015) en die Ned. Geref. Kerk (NGKO-2015). Die saak wat ondersoek word is die Skriftuurlike beginsels of konstantes van NGB artikel 36 vir die tema en die invloed van hierdie artikel op DKO-1619, GKSAKO-2015 en NGKO-2015

Vir die amptelike Afrikaanse vertaling van die NGB artikel 36 word die hersiene teks aanvaar wat deur Afrikaanse gereformeerde kerke aanvaar én deur die Algemene Sinode van die Ned. Geref. Kerk van 1982 goedgekeur is met 'dat ons kosbare konfessionele erfgoed met 'n nuwe lewenskragtigheid in ons kerk sal ... funksioneer' (NG KerkUitgewers 1982:5;9-38). Eerstens word die NGB of Confessio Belgica (Heyns 1992:38) artikel 36 vir sy hoofpunte en betekenis ontleed. Daarna kom die drie kerkordes aan die beurt en word hulle verhouding met NGB artikel 36 uitgepluis. Die ontleding word afgesluit met 'n slotgevolgtrekking.

Interessant genoeg loop die Afrikaanse teks van 1982 van die Drie Formuliere van Eenheid ongeveer gelyktydig met die Nuwe Afrikaanse Bybel van 1983. Dit is algemene kennis dat 'n amptelike nuwe direkte vertaling van die Bybel in Afrikaans op pad is en dat Bybelvertaling omrede verstaanbaarheid 'n voortgaande proses is. Taalontwikkeling is immers ook 'n voortgaande proses (Oberholster s.a.:84). Die gevolgtrekking kan dus gemaak word dat 'n nuwe vertaling van die Drie Formuliere ook op pad moet wees, maar helaas - in hierdie opsig is daar nie nuus nie. Net soos die Bybel as 'n geloofsboek met 'n geloofsdoel gelees moet word, netso moet belydenisskrifte as gesagvolle formulerings van die geloof verstaan word om 'lewenskragtig' in die lewe van die gereformeerdes te wees. 


\section{Die ontstaansgeskiedenis van die Nederlandse Geloofsbelydenis}

Die hoofsamesteller van die NGB is Guido (Guy) de Brés (15221567). De Brés word in Mons (Bergen in Henegouwen) gebore waar hy in die Rooms-Katolieke geloof opgevoed word. Hy raak vertroud met die oortuigings van die reformatore Luther en Calvyn en kies op 25-jarige ouderdom in 1547 vir die Hervorming. Vir die volgende paar jaar verskuif hy na London waar hy met Hervormers soos a' Lasco, Micron en Dathenus kontak het. Hy ontmoet Johannes Calvyn by verskeie geleenthede en word ' $n$ vurige Calvinis. In 1552-1556 is hy 'n rondreisende prediker in die suidelike Nederlande of België waar Luther groot steun geniet. Hier gee De Brés in 1555 sy 'Le Bastion de la Foy' (die staf van die geloof) uit. Hierna vlug hy as gevolg van sy geloof. Teen 1558 studeer hy by Calvyn in Genève én in Lausanne in Switserland. In 1559 word De Brés predikant in Doornik in België en in 1561 stel hy in sy 'tuinhuisje' die NGB saam (Oosthuizen 2008:209; Polman I s.a.:104). Deur die inkwisisie word De Brés vanweë beweerde 'kettery' ter dood veroordeel. Ten aanskoue van 'n groot skare word hy op 31 Mei 1567 in die openbaar gehang en sy lyk word dié dag daar laat hang voordat hy in 'n vlak graf begrawe word (Oosthuizen 2008:210).

De Brés druk sy eie stempel op die NGB af maar gebruik ook geskrifte soos die Franse Geloofsbelydenis (Confessio Gallica) van 1559 van Calvyn. Tussen die Nederlandse en hierdie Franse Geloofsbelydenis is daar sterk ooreenkomste wat vorm en inhoud betref. En, omdat Calvyn groot invloed op De Brés het, toon die Institusie van die hervormer'n merkbare invloed op die NGB. Aanvanklik poog De Brés om deur die NGB die Spaanse owerheid te oortuig dat die gereformeerdes of Calviniste nie 'n radikale groep wederdopers of Anabaptiste is nie en, anders as laasgenoemde, geen gevaar vir staatsowerhede in Wes-Europa inhou nie (Oosthuizen 2008:209). Hierin speel NGB artikel 36 'n sleutelrol. ${ }^{7}$ Daarop word terug gekom. Die Anabaptiste is hervormingsgesind, maar heg spiritualisties meer waarde aan die sogenaamde inwendige verligting van die menslike gees as die objektiewe gesag van die Woord van God en die leer van die kerk gebaseer op die Skrif - die invalshoek van Calvyn en De Brés (Heyns 1992:38). 'n Voorbeeld van die aanvaarding van die gesaghebbende objektiewe karakter van die Bybel is NGKO2015 artikel 1 waarvan die bewoording 50 jaar oud is (19622015) 'Die Ned. Geref. Kerk staan gegrond op die Bybel as die heilige en onfeilbare Woord van God' (NGKO-2015:1). Die konsekwensie hiervan is dat hierdie Woord heilig, onfeilbaar en onafhanklik van menslike insigte en emosies met goddellike gesag praat. Die objektiewe gesag van die Woord beteken dat die Woord as 'n geloofsboek met sy boodskap van verlossing in God drie-enig, selfstandig en betroubaar is. ' $\mathrm{n}$ Boodskap wat nie eers ontstaan wanneer mense dit hoor en as sulks beskou nie (NGK 1986:56, 611612; 2002:202-210, 548).

7. .n sy kommentaar op die NGB prat Polman van NGB artikel 36 as een van die mees . in Gede artike van hierdie konfessie. Hy wys ook op die werk van Calvyn en Beza in Geneve oor kerk en owerheid en De Bres se eie De Wortel en Le Bastion waarin hierdie gedagtes van De Brés oor kerk en owerheid ook voorkom (Polman IV s.a.:266-267).
Die NGB verskyn oorspronklik in Frans, maar word in 1562 ook in Nederlands en in Latyn vertaal. Nadat die belydenis deur vele gereformeerdes hanteer ${ }^{8}$ is, aanvaar die Dordtse Sinode op 30 April 1619 'n Nederlandse teks van die NGB wat daaraan - dit bly voorlopig - 'n gestandardiseerde karakter gee (Donner \& Van den Hoorn s.a.:307vv, 320-325).

\section{Die opgesomde inhoud van die Nederlandse Geloofsbelydenis}

S.A. Strauss noem die indeling van die NGB 'trinitarieshistories'. Dit wil sê die indeling van hierdie belydenis loop met die werk van die Vader, Seun en Heilige Gees volgens die openbaringsgeskiedenis van skepping, sondeval (soos in Genesis) en verlossing (soos in die Evangelies) deur tot die laaste oordeel (soos in Openbaring). Die NGB begin met die maniere waarop God Homself openbaar en die oorsprong, gesag, duidelikheid en genoegsaamheid van die Skrif as Gods Woord vir die hele Christelike lewe (S.A. Strauss 2008c:789). ${ }^{9}$ Die 37 artikels van die NGB handel opeenvolgend oor die middele waardeur God geken kan word, die Bybel, God drieenig, Jesus Christus en die Heilige Gees (artikel 1-11); daarna oor die skepping en voorsienigheid van God, die sondeval en erfsonde (artikel 12-15); verkiesing en verlossing (artikel 16-17); Jesus Christus (artikel 18-21); die heilsweldade (artikel 22-26); die kerk en die sakramente (artikel 27-35); en die owerheid en die laaste oordeel (artikel 36-37) (Heyns 1992:39; NG Kerk-Uitgewers 1982:9-38). Gemeet aan sy inhoud verwoord die NGB die essensiële aspekte van die Christelike geloof wat sy aanvanklike oogmerk om staatsowerhede soos Spanje - van die toelating en plek van die gereformeerde kerk in die samelewing te oortuig, bevorder.

Alhoewel die NGB in kerke met 'n Nederlands-gereformeerde konneksie aanvaar word, bly dit - in sy nabykonteks - een van die Drie Formuliere van Eenheid en - breër - een van verskeie gereformeerde konfessies (daar bestaan tussen 40-50) uit die sestiende eeu. Anders as die Lutherse kerke besit die gereformeerde kerke nie oor 'n afgebakende groep belydenisse nie. Hoewel hulle belydeniskrifte volgens Schulze 'basies' eenstemmig is, verskil hulle tog 'op sekere punte'. Calvyn wou nie 'n eie kerk stig nie en nie op die aanvaarding van sekere belydenisskrifte deur sy geesgenote aandring nie (Schulze 1978:204). Sy geestelike nasate sou ook nie sy naam dra nie, maar die meer kerklik-geestelike naam gereformeerd.

Polman skryf dat Giudo de Brés met 'blijmoedig geloofsvertrouwen zijn geloof met de marteldood bezegelde' (Polman I s.a.:105). By die aanhoor van sy doodsvonnis laat De Brés hoor:

Ik ben er zeer verblijd om en had nooit gedacht dat God mij zulk een eer zou aandoen ... Ik word van minuut tot minuut versterkt, ja mijn hart springt op van vreugde in mijn binnenste. (Polman I s.a.:108)

8.Polman IV (s.a.) verwys na "belangrijke tekswijzigingen' wat tot in die twintigste eeu aan die NGB aangebring is (p. 108).

9.Van Heyns kom die raak opmerking dat die Bybel iets oor alles in die skepping sê, maar nie alles oor alles nie. Volgens hom setel die gesag van die Woord in sy bedoeling naamlik om 'n 'heldere en magtige' boodskap by die mens uit te kry bedoeling naamlik om ' $n$ 'heldere en magtige' boodskap by die mens uit te kry -
'n boodskap oor God se lewensomvattende verlossing en vernuwing in Christus deur die Heilige Gees (Heyns 1973:145-147). 
Ten opsigte van die verhouding van die kerk met die staatsowerheid, kom Calvyn se standpunt oor die taak van die staat veral in hoofstuk 22 van sy vierde deel van die Institusie - die laaste hoofstuk - voor (Sizoo s.a.:555-595). Hierin fokus Calvyn op Bybelse vertrekpunte vir die burgerlike regering. Du Plessis noem die hoofstuk die 'fundamentele vertrekpunt' van Calvyn se houding oor die staat of sy 'regs- en staatsteorie' (Du Plessis 1977:97). Twee inleidende opmerkings is ter sake. Eerstens skryf Calvyn in die eerste uitgawe van sy Institusie in 1536 so oorwoë oor die saak dat hy dit onnodig ag om in latere uitgawes groot veranderinge aan te bring. Calvyn trek reeds hier sy Bybels verantwoordbare lyne oor die burgerlike owerheid (Balke 1973:59). Tweedens bly Calvyn in sy hantering van die saak homself getrou: hy is 'n Skrifeksegeet en teoloog en nie ' $n$ filosoof nie. Sy benadering is meer Bybels eties en selfs lewensbeskoulik as filosofies en staatsregtelik (Douma \& Van der Vegt 1978:2).

Calvyn vind die rede waarom die Here die staat ingestel het in Romeine 13:4: 'die owerheid is 'n dienaar van God tot jou beswil.' Die beswil van onderdane as - ook - 'n openbare, staatsgekoesterde belang, is sedert die sondeval van die mens onder groot druk en het die instelling van die staat deur die Here genoodsaak (Calvin 1947:477-479; Sizoo s.a.:559-568). Die beginsel dat die staatsowerheid 'n dienaar van God tot ons beswil is, word gesteun deur Romeine 13:1, 3 en 6 . Hierin word geopenbaar dat die owerheid en sy gesag 'n beskikking van God is, gehoorsaam moet word, die goeie moet prys en as ' $n$ dienaar van God belastings hef (Sizoo s.a.:559vv). Volgens Calvyn moet alle staatsowerhede daarop konsentreer dat hulle onderdane in hulle 'n beeld van God se voorsienigheid, bewaring, goedheid en regverdigheid sien. Billikheid teenoor almal waaroor hulle regeer, moet die grens van alle staatswette en -optredes wees (Du Plessis 1977:105; Schippers 1959:141; Sizoo s.a.:576). Die owerhede beklee 'n amp deur God ingestel en hulle oortredings of verontagsaming van sy gebooie, is 'n smaad vir God. Soos alle mense staan die staatsowerheid as owerheid onder albei tafels van God se gebooie of verbondswet (Sizoo s.a.:566). Daarom moet hy regverdig teenoor almal optree, die algemene vrede en rus bewaar én, gerugsteun deur sy monopolie oor die swaardmag, die Christelike godsdiens beskerm, God drie-enig erken en die gesonde leer verdedig (Sizoo s.a.:557). Die wette van die staat moet op Gods Wet gebaseer wees en vorm die senuwee van die staatshuishouding (Sizoo s.a.:574). ${ }^{10}$ 'n Verwerping van die gesag van die owerheid is 'n verwerping van die gesag van God (Du Plessis 1977:102; Sizoo s.a.:562).

Hiernaas is die owerheid òok 'n dienaar van God as hy die kwade straf, aldus Romeine 13:4 (Calvin 1947:480).

Teen hierdie agtergrond is die NGB oorspronklikgeformuleer. Die teks van 1561 is by die Sinode van Antwerpen in 1566, later hersien en in 1619 'uiteindelijk op die Synode van Dordrecht vastgesteld' (Polman I s.a.:108). In dié artikel word hierdie Dordtrechtse teks aanvanklik gebruik. Verdere wysigings sou volg ${ }^{11}$ totdat die Algemene Sinode van 1982 van die Ned. Geref. Kerk die Afrikaanse teks aanvaar het wat in hierdie kerk geld en as gesagvol aanvaar word (NG Kerk Uitgewers 1982:6). 'n Teks wat ook deur ander Afrikaanse gereformeerde kerke goedgekeur is (CJBF 2015:122-123).

\section{Nederlandse Geloofsbelydenis artikel 36 in 1619: die kerk en die burgerlike owerheid}

Ten einde ' $n$ behoorlike greep op NGB artikel 36 in sy Dordtse gewaad te kry, stel Polman vier stellings voor. Stellings wat die soms komplekse inhoud vir 'n huidige gereformeerd Westerse gemoed makliker verteerbaar maak. Polman noem artikel 36 sonder skroom een van 'de meest omstreden artikelen van onze Confessie.' 'n Konfessie wat altyd nog 'midden in de discussie' staan. Hierdie vier stellings of grondbeginsels bepaal die plek en funksie van die staatsowerheid by Johannes Calvyn, sy opvolger in Genève naamlik Theodore Beza én Guido de Brés. (Polman IV s.a.:266-275).

Die eerste stelling is dat elke skepsel of alle skepseldinge daar is om God te eer. Ook die staatsowerheid wat deur God vir sy eer ingestel is. Die tweede stelling is dat die owerheid in sy regering aan die Woord en in besonder aan die Wet (Tien Gebooie) van God vir sy optrede gebonde is. Die derde punt is dat die onderskeid én selfstandigheid van kerk en staat bedoel is om gehandhaaf word en die vierde dat hulle voortdurende samewerking 'n Bybelse eis is. By nadere ondersoek blyk hierdie vier stellings inderdaad uit die inhoud van NGB artikel 36.

Artikel 36 val weg met die oortuiging dat konings, prinse en staatsowerhede daar is as gevolg van die verdorwenheid van die menslike geslag. God wil dat die wêreld deur wette en regering beheer word om die losbandigheid van die mense in bedwang te hou en alles in goeie orde te laat verloop. Die 'overheid' het die swaard gekry om die kwaaddoeners te straf en die deugsames te beskerm. Die staatsowerheid moet egter nie net aandag gee aan die staatsbestuur en daaroor waak nie, maar sy hand ook hou aan die 'heilige' kerkdiens, afgodery en valse godsdiens uitroei, die ryk van die antichris vernietig en die koninkryk van Christus bevorder. Hy moet Gods Woord oral laat preek ('te doen prediking') sodat God deur almal geëer en gedien word soos Hy in sy Woord gebied. Verder is almal - alle mense - van watter hoedanigheid, rang of stand ookal, verplig om hulle aan die owerheid te onderwerp, belasting te betaal, die owerheid te eer en aan hom eerbied te betoon én hom in alle dinge te gehoorsaam wat nie stry met die Woord van God nie. Vir die owerheid moet gebid word dat die Here hom in al sy handelinge lei en sy onderdane 'n rustige en stil lewe kan lei - in eerbaarheid en Godsvrug. Ons of 'wij' verwerp die wederdopers en ander oproerige mense wat die owerheid en magistrate verwerp en die regsorde omver wil gooi. Mense wat die gemeenskaplike besit van

11.Juis ten opsigte van NGB artikel 36 deur die General Sinode van die Gereformeerde Kerke in Nederland van 1905 (Polman IV s.a.:290-291). 
goed wil invoer en die eerbaarheid wat God onder die mense ingestel het, versteur (vry vertaal uit Polman IV s.a.:266).

Polman se vier stellings pas op hierdie geformuleerde inhoud. 'n Owerheid wat alles billik en in goeie orde laat verloop, wat die wat goed doen prys en die wat kwaad doen straf, eer God deur sy werk as staatsowerheid. Daarby neem 'n staatsowerheid wat die ware Woord laat preek, afgodery en valse godsdiens uitroei en die ryk van die antichris vernietig, al Tien Gebooie van God vir sy rekening. Boonop beskerm die owerheid die kerk as 'n selfstandige geestelike instelling wat met geestelike middele soos die Woord oortuig, sonder om sy eie selfstandigheid as 'n instansie met die dwingende swaardmag in diens van algemene belang en billikheid, prys te gee. Die Nederlandse Geloofsbelydenis artikel 36 maak nêrens 'n einde aan hierdie samewerking tussen kerk en staat nie.

Die onmiddellike vraag wat opduik is egter: Neem die staat nie die selfstandige eie taak van die kerk oor as hy die ware Woord beoordeel en laat preek nie? Die gepredikte Woord is juis ' $n$ instrument wat die kerk vanuit sy aard as 'n geloofsverband aanwend. Is die swaardmag van die staatsowerheid die sleutel om alle afgodsdiens en afgodery as, ten diepste geestelike verskynsels, met wortel en tak uit te roei? Is effektiewe weerstand teen afgodery en afgodsdiens beperk tot die fisiese weerstand van die swaardmag? Bestaan 'n kerklike belydenis van geloof in God drie-enig nie uit geloofswaarhede wat van harte geglo moet word om eg bely te word nie? De Brés erken dat niemand tot 'n ware geloof in God gedwing - deur staatsdwang - kan word nie, maar tog handhaaf hy die reg van die owerheid of magistraat om ketters te straf (Polman IV s.a.:281). In dié verband steun hy selfs die doodstraf indien dit nodig is. ' $\mathrm{n}$ Straf waarvoor hy hom op Eksodus 22:20 en Deuteronomium 13:1vv beroep (Polman IV s.a.:285). Op sy beurt onderstreep Beza die houding van Calvyn en NGB artikel 36 metsy opmerking dat staatsowerhede van tyd tot tyd tot ander oortuigings kom, maar dat die Here as wetgewer nie van sy gebooie as norme vir kerk en staat afgesien het nie en gehoorsaamheid van beide eis. Hy is en bly immers God en nie 'n mens nie (Polman IV s.a.:274).

\section{Nederlandse Geloofsbelydenis artikel $\mathbf{3 6}$ gewysig}

Nederlandse Geloofsbelydenis artikel 36 uit 1619 plaas konsekwente gereformeerdes wat op kerklike oortuiging deur die Woord en Gees van God - ook soos Calvyn - staan, dus voor 'n probleem. Daarom skrap die Generale Sinode van 1905 van die Gereformeerde Kerke in Nederland daardie sinsnede uit die Dordtse NGB artikel 36 dat die owerheid deur dwang alle afgodery en valse godsdiens asook die ryk van die antichris, moet uitroei (Polman IV s.a.:291). 'n Wysiging wat vanuit 'n groep neo-Calvinistiese denkers ${ }^{12}$ waaronder Abraham Kuyper en van sy medestanders met hulle neo-Calvinistiese wysbegeerte, geloods word.

\footnotetext{
12.Bekende gereformeerdes onder hierdie denkers is F.L. Rutgers, P. Biesterveld en H.Bavinck (Polman IV s.a.:290)
}

Polman het gelyk: oor hierdie artikel van NGB praat die kerk nie klaar nie.

Voor die eerste vergadering van die Gereformeerde Ekumeniese Sinode, die Sinode van Amsterdam van 1949, dien 'n rapport van die Gereformeerde Kerk in Suid-Afrika en die Christian Reformed Church in North America oor die wysiging van NGB artikel 36 in sy Dordtse baadjie. Die Sinode besluit op 'n verklaring oor die saak wat aan lidkerke uitgestuur word. Die vergadering verklaar ondermeer dat die staatsowerheid daaraan moet meewerk dat die ontplooiing van die menslike lewe aan die hand van beide tafels van die Tien Gebooie plaasvind; dat die owerheid kerklike diens en die prediking van die Woord moet beskerm - nie oorneem of self ter hand neem nie - om die gewetensvryheid van die gelowiges om God met leer en lewe te dien soos Hy wil, te waarborg én antichristelike pogings wat die kerk in die uitvoering van sy opdrag mag strem, te verhinder; en dat die kerk die owerheid vir die uitvoering van hierdie taak as sy eie tipiese diens aan God, sal erken en eer (Polman IV s.a.:292). Op die volgende Ekumeniese Sinode, die van Edinburgh in 1953, dien 'n voorstel van die Generale Sinode van die Gereformeerde Kerke in Nederland om NGB artikel 36 so te wysig dat dit aan die owerheid opgedra word om enige belemmering vir die ware godsdiens en prediking van die Woord, deur dwang weg te neem (Polman IV s.a.:293). Die klem in dié wysiging val dus nie meer op die owerheid om ten opsigte van die prediking en geloof plaasvervangend vir die kerk te wees nie, maar die regsruimte waarbinne die kerk sy geloofswerk doen met sy monopolie van die swaardmag te waarborg. Die Gereformeerde Ekumeniese Sinode wat nie die besluite oor die inhoud van belydenisskrifte uit die hande van die lidkerke wil neem nie, staan hiermee verder as Calvyn en De Brés oor die taak van die staat as 'n regsverband. Die moderne samelewings waarin die twintigste eeuse gereformeerdes hulle bevind, is nie meer die teokratiese verbonds- of eenheidsgemeenskappe van Calvyn en ander na die Reformasie nie, maar humanities demokratiese, menseregte-gerigte gemeenskappe. Daarby oefen neoCalviniste soos Dooyeweerd, Dijk en De Graaff wat die staat nie as 'n waardige plaasvervangers vir die kerk beskou nie, teen 1950 invloed op gereformeerde Nederland uit (Polman IV s.a.:304; Strauss 1994:195-214). ${ }^{13}$

Gereformeerde Nederland vorm vir jare die plek vir nagraadse teologiese studente uit gereformeerde SuidAfrika. In die 1900's volg daar 'n konsentrasie hiervan by die Vrye Universiteit (VU) in Amsterdam - die produk van Abraham Kuyper (1837-1920) en sy geestelike navolgers wat ontstaan in 1880 (P.J. Strauss 2008:634). Dit geld veral die Ned. Geref. Kerk wie se NGKO-2015 oor die kerk en die burgerlike owerheid aanstons belig word. Sedert die eerste student in 1907 en tot en met 1952 skryf sestig predikante van die Ned. Geref. Kerk nagraads in aan die VU. Van die twintig 13.Vgl. byvoorbeeld Nauta (1971:121-130) oor die gesag en aard van kerkvergaderinge.
Sy benadering is klaarblyklik neo-Calvinisties of Kuyperiaans-Dooyeweerd
georiënteerd. ' $n$ Benadering wat meewerk aan GKNKO 1959 se karakter van 'Die Dordtse Kerkorde aangepas by die eise van die dag.' 
teologiese proffesore wat van 1907 tot 1952 in die Ned. Geref. Kerk doseer, studeer tien aan die VU - almal na 1907. Die VU vervang Utrecht in Nederland in die eerste helfte van die twintigste eeu as die gewildste plek in die buiteland vir die nagraadse studie van Ned. Geref. Kerk-predikante (Odendaal 1952:252). Hoewel hierdie studente waarskynlik nie almal tot dieselfde mate beïnvloed word nie, verklaar hierdie agtergrond die invloed van die Kuyperiaanse neo-Calvinisme op die eerste Kerkorde van die Algemene Sinode van die Ned. Geref. Kerk, NGKO-1962, en ander besluite van die Algemene Sinode in hierdie tyd (Strauss 1993:15-17; 1994:203-208). Eie aan die tradisie in gereformeerde Nederland, sou hierdie invloed studente positief instel teenoor die Dordtse Sinode van 1618-1619 en 'n invloed hê op die nawerking van die konfessionele (Drie Formuliere van Eenheid) en kerkordelike besluite (DKO 1619) van hierdie Sinode van 1618-1619 op hierdie studente. Vir J.D. Vorster (1960) as die sameroeper van die kommissie van aktuarii wat die eerste Kerkorde van die nuwe Algemene Sinode van die Ned. Geref. Kerk, NGKO-1962, moes opstel, was die Dordtse konneksie van dié Kerkorde so belangrik, dat hy dit 'die Dordtse Kerkorde aangepas by die eise van ons dag' genoem het (p. 13).

Hoe dit ookal sy, teen 1982 het die Algemene Sinode van die Ned. Geref. Kerk 'n nuwe vertaling van die NGB aanvaar wat die probeem in artikel 36 anders verwoord en 'n draai aan die betekenis gee wat die kritiek vanuit 'n neoCalvinistiese oord tegemoet kom. 'n Behoefte wat ook in die Ned. Geref. Kerk ontstaan het en gevoed is deur sy kontak met gereformeerde Nederland (Strauss 1993:14, 15).

Hierdie Afrikaanse vertaling van NGB artikel 36 sny al die punte van die oorspronklike artikel korrek en verstaanbaar aan. Die omstrede kwessies om sy hand aan die kerkdiens te hou, die Woord oral te laat verkondig en alle afgodery, valse godsdiens en die ryk van die antichris te vernietig, word met 'n nuwe paragrafie vervang. ' $n$ Betekenis wat moontlik in die destydse Gereformeerde Ekumeniese Sinode (dit is in 2010 in Grand Rapids in die Wêreldgemeenskap van Gereformeerde Kerke opgeneem) aanvaarbaar sou wees. Hierdie paragrafie gee aan die staatsowerheid die nuutgeformuleerde opdrag:

$[O] \mathrm{m}$ die heilige Woordbediening te beskerm om sodoende alle afgodery en valse godsdiens teen te gaan en uit te roei, die ryk van die Antichris te vernietig en die koninkryk van Jesus Christus te bevorder en oral te laat verkondig sodat God deur elkeen geëer en gedien word, soos hy in sy Woord beveel. (NG Kerk-Uitgewers 1982:36)

Die woorde 'sodoende' en 'laat verkondig' neem 'n strategiese plek in. Dit kom daarop neer dat die staat as 'n juridiese integrator en versorger van die regsbelange van almal in sy gebied, deur sy regsorde die reg van die kerk beskerm en hom waarborg om die Woord te kan bedien én 'sodoende' afgodiese magte, valse godsdiens en die ryk van die Antichris te vernietig (Fowler 1988:36-39). Die kerk wat deur die bediening van die Woord as sy primêre taak die koninkryk van Christus bevorder en oral verkondig of 'laat verkondig' dat die Here deur almal gedien en geëer moet word soos Hy in sy Woord beveel. Dié formulering 'beveilig' die kerk (Nauta 1971:9) wat daarop ingestel moet wees om deur geestelike middele - Woord en sakrament - tot geloof te oortuig (en nie fisies te dwing nie) én 'beperk' die staatsowerheid tot sy roeping deur God naamlik die handhawing van die reg gerugsteun deur die fisiese swaardmag, van almal in sy gebied (Fowler 1988:28).

Die Drie Formuliere van Eenheid soos aanvaar by die Dordtse Sinode in 1619, moes deurwerk op die DKO-1619 wat daarna deur die afgevaardigdes vanuit die Nederlandse Kerke aanvaar is. Die Formuliere was as norma normata of tweede norm naas die Bybel as norma normans of eerste norm, immers ook normatief vir DKO 1619. Gesien die volgorde waarin die Drie Formuliere en die DKO-1619 daarna deur die Sinode aanvaar is, is dit duidelik dat die DKO-1619 in 'n klimaat wat positief vir NGB artikel 36 moes wees, goedgekeur is.

\section{Nederlandse Geloofsbelydenis atikel 36 en Dordtse Kerkorde 1619 artikel 28: die kerk en die burgerlike owerheid}

Die Dordtse Kerkorde-1619 heg 'n eenvoudige opskriffie aan artikel 28, naamlik 'Overheden'. Anders as NGB artikel 36 wat sy Bybelse lyne, soos hy dit verstaan, vir die staatsowerheid en sy taak trek, gaan DKO-1619 artikel 28 van 'n vergelyking uit.

Artikel 28 aanvaar dat die destydse staatsowerheid in Nederland, waarin kerk en staat as twee kante van dieselfde munt en die gemeenskap as 'n eenheidsgemeenskap beskou is, 'n Christelike owerheid met 'n positiewe waardering vir die Gereformeerde Kerk is. In die situasie waarin DKO-1619 geld, is hierdie gesindheid 'n nie-omstrede gegewe. Anders as NGB artikel 36 trek die DKO-1619 nie prinsipiële lyne vir die taak van staat én kerk nie, maar reël dit, as ordemaatreëls vir die doen en late van die kerk, die houding en optrede van die Gereformeerde Kerk as kerk teenoor die staatsowerheid. Die kerk kan Skrifwaarhede vir die funksionering van die staatsowerheid bely en die owerheid van die noodsaak daarvan oortuig - deur die swaard van die Gees of Woord van God - maar die owerheid nie deur sy kerkorde aan sekere take bind nie. 'n Kerkorde tref ordereëlings vir die kerk en die staatsowerheid kan kerklike besluite - ook die wat hom raak - slegs aanvaar as hyself van die nut daarvan oortuig is en besluit om die staatsapparaat - in sy beheer oor die swaardmag - daarvoor aan te wend (Fowler 1988:26).

Die Dordtse Kerkorde artikel 28 oor die staatsowerheid begin met ' $n$ veronderstelling (gegewe) en 'n vergelyking: soos die Christelike owerheid die 'heiligen kerkedienst' (dieselfde begrip in NGB artikel 36) op alle maniere bevorder en deur sy voorbeeld by sy onderdane aanbeveel én aan kerklike ampsdraers wanneer nodig, hulp verleen én deur sy orde die kerk beskerm, so moet die predikant, ouderling en diaken die hele gemeente vlytig en opreg opskerp om die 
gehoorsaamheid, liefde en eerbied wat aan hom verskuldig is, aan die owerheid te bewys. Alle kerklike persone (ampsdraers?) moet deur hulle voorbeeld die gemeente hierin voorgaan en deur hulle agting en korrespondensie die guns van die owerhede vir die kerk soek, opwek en behou. As elkeen sy plig hieroor in die vrese van die Here nakom, (alle) agterdog en wantroue vermy en eensgesind is, dien dit die belang van die kerke (vertaal uit ou Nederlands in Pont [1981:179] en vergelyk met ' $n$ min of meer direkte vertaling in ouer Afrikaans in GKSAKO-1966 in Du Plessis [1966:167168], én 'n nuwe vertaling in Afrikaans in Visser [1999:121]).

Sonder om dit te beklemtoon, is die DKO-1619 artikel 28 minder skerp oor die staat as 'n plaasvervanger of werktuig van die kerk met kerklike middele. Kerklike ampsdraers word wel vir - ongekwalifiseerd - hulp deur die staat aangewys, maar die staat word nie genoem as een wat sy hand aan die kerkdiens moet hou, die Woord oral laat preek en die antichris uitroei nie. Miskien word dié taak as 'n NGBof belydeniskwessie en normatief vir die DKO-1619 hier veronderstel. Om die 'heiligen kerkdienst' op alle maniere te bevorder word in die DKO-1619 artikel 28 breed en ongespesifiseerd aangevoor en kan twee betekenisse inhou: òf die oorname van ' $n$ tipiese kerklike diens met kerklike middele òf die beskerming van hierdie diens deur 'n regsbepaalde orde in die samelewing. Dordtse Kerkorde-1619 artikel 28 se stelling dat die kerk deur die orde van die staatsowerheid beskerm word, neig in die rigting van laasgenoemde. Dit open die moontlikheid dat die sin en betekenis van die staat vir die kerk juis in die uitvoering van sy godgegewe roeping lê: om 'n regsorde in stand te hou waarbinne die kerk as 'n geloofs- en geestelike instelling in geloofsvryheid sy godgegewe roeping kan vervul (Fowler 1988:28).

Die goeie verhouding tussen die Gereformeerde Kerk en die Nederlandse staatsowerheid in die goue sewentiende eeu in Nederland word weerspieël in beide die NGB en DKO-1619 as produkte van die Nasionale Sinode van Dordrecht van 1618-1619. Hulle werk met dieselfde owerheid van wie hulle begrip vir die kerk en sy taak verwag en altwee word teen die einde van die Sinode, in April-Mei 1619, aanvaar (Donner \& Van den Hoorn s.a.:325; Kuyper s.a.:107vv).

Die band tussen die NGB artikel 36, die GKSAKO-2015 en NGKO-2015 beweeg in die Dordtse tradisie, maar elkeen ook op 'n eie pad.

\section{Nederlandse Geloofsbelydenis artikel 36 en Kerkordes van die Gereformeerde Kerke in Suid- Afrika-2015: die kerk en die burgerlike regering}

Getrou aan sy styl herhaal die GKSAKO-2015 die struktuur en inhoud van die DKO-1619 artikel 28 tot 'n groot mate. Enkele nuanseringe toon egter dat die Gereformeerde Kerke in Suid-Afrika kerkordelik wel hulle eie pad met hulle eie variasie - van DKO-1619 - loop. Tog lê die invloed van die DKO-1619 baie duidelik op die GKSAKO-2015. Nie slegs die bewoording herinner aan die DKO artikel 28 nie, maar in GKSAKO-2015 is die saak van die kerk en die burgerlike owerheid eweneens vervat in artikel 28.

Teen 2015 is die Afrikaanse vertaling van die NGB wat in 1982 deur die Ned. Geref. Kerk aanvaar is, ook in die Gereformeerde Kerke in Suid-Afrika geldig (CJBF 2015:122123; GKSA 1949:325-326). Vir die doel van hierdie artikel moet die GKSAKO-2015 artikel 28 dus met hierdie vertaling van die NGB in verband gebring word.

Soos die DKO-1619 artikel 28 begin die GKSAKO-artikel 28 ook met 'n vergelyking. Soos dit die plig van die staatsowerhede as instellings van God is om aan die kerk en sy ampsdraers hulp en beskerming te verleen, so is dit die plig van alle predikante, ouderlinge en diakens om die gehoorsaamheid en eerbied wat aan die staatsowerheid verskuldig is, gereeld en ywerig by die gemeente in te skerp. Hulle moet in die vrees van die Here die guns van die owerheid teenoor die kerke of gemeentes opwek én behou in belang van die kerke. Dit is die plig van kerklike vergaderings om korrespondensie met die owerheid te voer om sy medewerking te verkry en 'in voorkomende gevalle as kerk van Christus voor die owerheid te getuig' (CJBF 2015:23).

Kerkordes van die Gereformeerde Kerke in Suid-Afrika artikel 28 se verskille met die DKO-1619 artikel 28 vertoon die verskil in eietydse omstandighede tussen hulle: die omstandighede van die DKO-1619 in Nederland in 1619 met ' $n$ doelbewuste Christelike owerheid en die van die GKSAKO-2015 in Suid-Afrika voor 1994 met die Nasionale Party wat op daardie stadium nie sondermeer op steun uit die Gereformeerde Kerke kon reken nie en na 1994 van die African National Congress (ANC) wat nie sondermeer 'n Christelike owerheid genoem kan word nie.

Teenoor die DKO-1619 se Christelike owerheid wat die heilige kerkdiens op alle maniere bevorder, noem GKSAKO net die owerhede - ongekwalifiseerd - wat aan die kerk - hulp en beskerming bied. In sy huidige vorm word die GKSAKO-2015 artikel 28 in 1967 goedgekeur en na 1994 die verandering van regering in Suid-Afrika onveranderd gelaat (Van der Linde 1983:116). Die klem val nie op 'n Christelike owerheid nie, maar op 'n ongekwalifiseerde owerheid wat daar is deur Romeine 13:1 se 'beskikking van God'; 'n owerheid wat die kerk se reg op vryheid van die Bybelse godsdiens handhaaf, al spruit hierdie houding uit die Suid-Afrikaanse Grondwet van 1996 met sy akte van regte en vryheid van godsdiens. Kerkordes van die Gereformeerde Kerke in Suid-Afrika artikel 28 se staatshulp en -beskerming aan die kerk mik in 2015 waarskynlik op die staatswaarborg van vryheid van godsdiens in die lig van hierdie Grondwet (Rautenbach \& Malherbe 1994:13). Kerklike ampsdraers is volgens GKSAKO artikel 28 egter nié getaak om soos sy Dordtse eweknie die gemeente tot liefde vir die owerheid aan te spoor nie, hoewel die gehoorsaamheid en eerbied vir die owerheid van hierdie eweknie kwalifiseer. Die Vyfde Gebod en Romeine 13 het - as 
steun vir GKSAKO artikel 28 - alle owerhede in die oog. Volgens die GKSAKO moet die kerklike ampte hulle daarvoor beywer dat die owerheid die kerke (hier die Gereformeerde Kerke of gemeentes in Suid-Afrika) in 'n gunstige lig sien. Kerkvergaderings naamlik kerkrade, klasses en sinodes kry in GKSAKO artikel 28 die opdrag om korrespondensie met 'die owerheid' te voer om sy medewerking te verkry en so 'n kanaal oop te hou om in 'voorkomende gevalle' as kerk van Christus teenoor die owerheid te getuig. Die laaste opdrag is 'n ontwikkeling wat na DKO-1619 kom. Daarby wil 'voorkomende gevalle' as 'n nuwe kerkordelike tegniese term, 'n nuwe 'Dopperterm', '14 waarskynlik dat die situasie van die kerk oortuig om as kerk vanuit 'n kerklike hoek sy standpant oor 'n saak aan die owerheid deur te gee.

Met sy staatsowerhede - ongekwalifiseerd - as 'n beskikking van God, staan GKSAKO artikel 28 nader aan NGB artikel 36 as aan die DKO-1619 artikel 28. Sy hulp en beskerming van die kerk deur die owerheid dui waarskynlik - soos die NGB met 'sodoende' -op die handhawing van 'n openbare regsorde deur die staatsowerheid waarin die kerk sy taak as 'n Christelike geloofsverband vervul, al is die vertrekpunt van hierdie owerheid ' $n$ humanisties gefundeerde akte van menseregte. Die Here se opdrag aan die staat om die reg te handhaaf soos God dit wil (Ps 72:1) en die akte met sy vryheid van godsdiens is tot almal se regs- en geloofsvoordeel. Van 'n oorgee van tipies kerklike werk aan die staat is daar by die GKSAKO-2015 in die Suid-Afrika van 2015 egter nie sprake nie. Daarby moet die kerke onder gelowiges en niegelowiges guns verwerf deur eerbare en omgee optrede. Korrespondensie of kontak met die staatsowerheid bly 'n aanbeveling vir enige kerk met die boodskap van die Bybel: so was dit in 1619 in Nederland met die Christelike owerheid en so is dit in 2015 in Suid-Afrika met die ANC-owerheid. Hierdie profetiese taak teenoor almal in 'n gebroke wêreld lê op die weg van die kerk - waar en wanneer ookal.

Waar GKSAKO na struktuur en inhoud 'n meer direkte aanpassing van DKO-1619 by die eise van 2015 is, slaan NGKO-2015 tot ' $n$ groter mate in die nuwe tyd 'n eie koers met sy inhoud in. ' $n$ Inhoud wat op plekke herinner aan die Kerkorde van die Gereformeerde Kerke in Nederland van 1959 wat deur die eerste NGKO, NGKO-1962, as voorbeeld gebruik is. Die Ned. Geref. Kerk handhaaf wel die hoofstukindeling, sekere prinsipiële lyne en bewoordings van die DKO-1619. Bepalings van NGKO-2015 oor die Ned. Geref. Kerk en die staat word vervat in hoofstuk 6 oor betrekkinge van die kerk na buite. Hier staan dit onder die opskrif kerk en staat in artikel 67 (NGKO-2015:21).

\section{Nederlandse Geloofsbelydenis artikel 36 en Ned. Geref. Kerk -2015: kerk en staat}

Die Ned. Geref. Kerk-2015 artikel 67 het 'n voorganger uit 1962 wat ruimskoots gebruik maak van neo-Calvinistiese

14.Die Gereformeerde Kerke in Suid-Afrika ontleen die bynaam "Doppers of Dopperkerk' aan die Afrikaanse gemeenskap waarin hy in 1859 ontstaan he (Spoelstra 1963:19). terme soos soewerein in eie kring en selfstandigheid in eie bevoegdheid, publiekregtelike terrein en moderne gedifferensieerde samelewing. Daarby spruit NGKO-1962 artikel 65 uit die onlusgeteisterde Suid-Afrika na die Sharpville van 21 Maart 1960 waarin die Afrikanergemeenskap van destyds geledere gesluit het rondom premier Verwoerd teen die wêreldwye vloedgolf van kritiek teen apartheid (Strauss 2001:336). In hierdie situasie van veroordeling het die Ned. Geref. Kerk in artikel 65c van die NGKO-1962 hom genoodsaak geag om sy dankbaarheid te betuig teenoor die staatsowerheid in SuidAfrika vir sy (regs)beskerming. Hy het ook sy voorneme te kenne gegee om nie sy vryheid van godsdiens te misbruik om - soos die ANC en die Suid-Afrikaanse Kommunistiese Party wat daarom destyds verbode verklaar is - die 'fondamente van die staatsgesag te ondergrawe of wanorde op publiekregtelike terrein te veroorsaak nie' (NGK 1964:1415). Sy staatsowerheid en sy vaderland het deurgeloop en in hierdie situasie kon die NGKO-1962 - soos die DKO-1619 in Nederland van sy ondersteuning en goeie verhouding met die staatsowerheid getuig - sy solidariteit met sy owerheid kwalik stil hou (Treurnicht 1961:45).

Die Ned. Geref. Kerk-1998 sou met 'n hersiene artikel 65 oor kerk en staat kom.

Juis omdat die NGKO-1998 die orde van en vir die Ned. Geref. Kerk is, is artikel 65 gerig op die optrede van die Ned. Geref. Kerk teenoor die staat en staatsowerheid (Strauss 2001:333). Die Ned. Geref. Kerk-1998 aanvaar Romeine 13 as 'n norm of 'n gegewe vir die kerk in sy houding teenoor die staat. ' $n$ De facto regering is deur God beskik en daarom is hy ook de iure (vgl. Strauss 2010:129 teenoor Van Niekerk 1987:11vv). Die staatsowerheid het die opdrag van God om die reg in die gemeenskap en daarbuite te handhaaf en kwaaddoeners te straf. Die Bybel is die norm vir die kerk se deelname aan die publieke regsverkeer en uitoefening van burgerlike regte. Die kerk maak aanspraak op vryheid van godsdiens wat sy Bybels-profetiese getuienis teenoor die owerheid insluit. 'n Vryheid waarvoor die kerk op die regsbepaalde beskerming van die staat aanspraak maak. Die Ned. Geref. Kerk skakel en/of praat deur kerkvergaderings en kommissies met die owerheid (NGKO1998:26; vgl. NGKO-2015:21).

Die Ned. Geref. Kerk-artikel 67 ontken dus nie dat kerk en staat beide deur God beskik is en in sy diens staan nie. Die artikel staan steeds in die greep van die neo-Calvinisme. Hiervolgens is die kerk as 'n geloofsverband gerig op die Christelike geloof en Bybels-profeties daarmee getaak terwyl die staat in sy juridiese taak die regsruimte waarborg waarbinne die kerk hierdie taak in vryheid kan verrig. Kerk en staat is volgens die NGKO-2015 albei soewerein in eie kring, maar deur raakvlakke in hulle tipiese eie take ook universeel in eie kring. Die staat moet die kerk as kerk herken om hom te kan beregtig en die kerk moet die staat as staat herken om sy profetiese stem toepaslik en relevant te rig. Die staatsowerheid en staat kan die geloofsbelang van die kerk kruis met ' $n$ on-Bybelse wet of aksie en die kerk kan die 
regsbelang van die staat kruis as hy weier om staatswette in sy kerkwees te gehoorsaam. Wette wat - byvoorbeeld - die openbare orde of eiendomsreg reël.

Die Ned. Geref. Kerk-2015 erken hierdie opvatting en spel die kerk se optrede teenoor die staat daarmee kerkordelik verantwoord uit.

\section{Slot}

Met 'n gereformeerde kerk se belydenisskrifte wat as normatief vir sy kerkorde beskou word, moét NGB artikel 36 oor die burgerlike owerheid ' $n$ invloed hê op die DKO-1619, GKSAKO-2015 en NGKO-2015. Hierdie invloed is ook in hulle bepalings vir kerk en staat in hierdie kerkordes merkbaar.

Soos 'n gereformeerde kerkorde dra die DKO-1619 ook tekens van sy verhouding met die Nederlandse staatsowerheid van sy tyd. Dieselfde geld vir die GKSAKO-2015 en NGKO-2015 en die owerheid in SuidAfrika. Dit kan nie anders nie, omdat 'n gereformeerde kerkorde met sy maatreëls eietyds en toepaslik moet wees (Strauss 2010:15vv). Die kerk as 'n geloofsverband moet sy belydenis en take egter Bybels-konfessioneel én eietyds of gepas in die betrokke situasie uitleef en die staat as 'n regsverband moet sy implimentering van geregtigheid aan almal - 'n begrip wat òò in 'n eietydse waardesisteem gegiet word - ten diepste Bybels begrond. Die staat bly gebonde aan God se gebod al erken hy nie die gebod nie. Regverdigheid en reg as skeppingsgegewes staan vas al ignoreer mense dit. Die Here se gebooie is geldig onafhanklik van menslike erkenning. God wat soewerein en onafhanklik is, sit op die troon en het besluit om daar te bly.

Hierdie uitgangspunt word weerspieël in die drie kerkordes wat bekyk word en klop met die eerste grondbeginsel wat Polman aanvoer vir die verstaan van NGB artikel 36 - alles tot eer van God. Die drie kerkordes verstaan kerk en staat as 'n verhouding wat jy nie sonder die Bybel peil nie en as instellings wat sy vierde grondbeginsel moet waarmaak: hulle moet mekaar respekteer en aanvul - die kerk uit 'n geloofsen die staat uit'n regshoek. Wat die DKO-1619, GKSAKO-2015 en NGKO-2015 ook impliseer is Polman se tweede grondbeginsel: dat beide kerk en staat gebonde is aan die Here se struktuuropdrag vir hulle gehoorsame, gesonde funksionering: die Tweede Gebod wat die Here as die enigste wetgewer erken. Daarby handhaaf die drie kerkordes die eie aard of taak van kerk en staat - NGKO-1962 praat nog van soewerein in eie kring - wat hulle optrede in die samelewing en teenoor mekaar bepaal: die derde grondbeginsel wat Polman noem.

Die kerk groei en ontwikkel in sy geloof met die Woord as lewensnorm, 'n norm of kern van die lewe - God is die Skepper van hemel en aarde én daarby die gewer van lewewat ook vir die staat in sy handhawing en ontwikkeling van die reg geld. Daarom gaan dit in die NGB artikel 36, DKO1619 artikel 28, GKSAKO-2015 artikel 28 en NGKO-2015 artikel 67 om kerk en staat wat elkeen in die uitvoering van sy taak ten diepste Woordgehoorsaam moet wees.

\section{Erkenning Mededingende belange}

Die outeur verklaar dat hy geen finansiële of persoonlike verbintenis het met enige party wat hom nadelig kon beïnvloed in die skryf van hierdie artikel nie.

\section{Outersbydrae}

P.J.S. was die enigeste outeur betrokke by die skryf van die artikel.

\section{Etiese oorwegings}

Hierdie artikel voldoen aan alle etiese standaarde vir navorsing sonder direkte kontak met mens of dier.

\section{Befondsing}

Hierdie navorsing het geen spesifieke befondsing van enige befondsingsagentskap in die openbare, kommersiële of niewinsgewende sektore ontvang nie.

\section{Data beskikbaarheidsverklaring}

Die deel van data is nie van toepassing vir hierdie artikel nie omdat geen nuwe data in tydens die studie geskep of geanaliseer is nie.

\section{Vrywaring}

Die menings en opinies wat in hierdie artikel verwoord word is dié van die outeur en reflekteer nie die amptelike beleid of posisie van die geaffilieerde agentskap van die outeur nie.

\section{Literatuurverwysings}

Balke, W., 1973, Calvijn en de doperse radikalen, Ton Bolland, Amsterdam.

Bouwman, H., 1985, Gereformeerd Kerkrecht II, De Groot Goudriaan (3e druk), Kampen.

Calvin, J., 1947, Commentaries on the epistle of Paul the apostle to the Romans, Eerdmans, Grand Rapids, MI.

Celliers, A., 2003, Skrif en Kerkorde. Enkele konstantes vanuit ' $n$ veelkantige beeld, Universiteit van die Vrystaat (ongepubliseer), Bloemfontein.

CJBF, 2015, Kerkordeboekie van die Gereformeerde Kerke in Suid-Afrika, CJBF, Potchefstrooom.

Degenaar, J., 1996, 'Red demokrasie in Suid-Afrika van Jakobyne en populiste', Die Volksblad, 9, 27 Julie.

Donner, J.H. \& Van den Hoorn, S.A., s.a., Acta Nationale Synode te Dordrecht, Donner, Leiden.

Douma, J. \& Van der Vegt, W.H., 1978, Het gepredikte Woord, Wever, Franeker.

Du Plessis, H.L.M., 1966, 'Ampsdraers en owerhede', in L.S. Kruger, H.L.M. Du Plessis, B. Spoelstra \& T.T. Spoelstra (reds.), Handleiding by die Kerkorde, pp. 167-171, Pro Rege, Potchefstroom.

Du Plessis, L.M., 1977, Calvyn oor die staat en die reg, 2e druk, PU vir CHO, Potchefstroom.

Engelhard, D.H. \& Hofman, L.J., 2001, Manual of Christian Reformed Church Government, CRC Publications, Grand Rapids, MI.

Fowler, S., 1988, The state in the light of the Scriptures, Institute of Reformational Studies, Potchefstroom.

Gereformeerde Kerk in Suid-Afrika (GKSA), 1949, Acta Sinode 1949, s.n., s.I.

Heyns, J.A., 1973, Die brug tussen God en mens, NG Kerk-Uitgewers, Kaapstad.

Heyns, J.A., 1977, Die Kerk, NG Kerkboekhandel, Pretoria. 
Heyns, J.A., 1992, Inleiding tot die dogmatiek, NG Boekhandel 1988, Halfway House. Jonker, W.D., 1994, Bevrydende waarheid, Hugenote-Uitgewers, Wellington.

Kleynhans, E.P.J., 1988, Gereformeerde Kerkreg IV, NG Kerkboekhandel Transvaal, Pretoria.

Kuyper, H.H., s.a., De Post-acta of nahandelingen van de Nationale Synode van Dordreckt in 1618 en 1619 gehouden, Höveker en Wormser, Amsterdam.

Nauta, D., 1971, Verklaring van de Kerkorde van de Gereformeerde Kerken in Nederland, Kok, Kampen.

Nederduitse Gereformeerde Kerk, 1962, Die Kerkorde van die Nederduitse Gerefeformeerde Kerk (NGKO), Hugenote-Uitgewers, Wellington.

Nederduitse Gereformeerde Kerk, 1964, Die Kerkorde van die Nederduitse Gerefeformeerde Kerk (NGKO), Hugenote-Uitgewers, Wellington.

Nederduitse Gereformeerde Kerk, 1982, Ons glo ... Die drie formuliere van eenheid en ekumeniese belydenisse, Hugenote-Uitgewers, Wellington.

Nederduitse Gereformeerde Kerk, [1986] 2002, Handelinge van die Algemene Sinode, Hugenote-Uitgewers, Wellington.

Nederduitse Gereformeerde Kerk, 1998, Die Kerkorde van die Nederduitse Gerefeformeerde Kerk (NGKO), Hugenote-Uitgewers, Wellington.

Nederduitse Gereformeerde Kerk, 2015, Die Kerkorde van die Nederduitse Gerefeformeerde Kerk (NGKO), Hugenote-Uitgewers, Wellington.

Oberholster, J.A.S., 2021, Die Bybel in Afrikaans, NG Kerk-Uitgewers, Kaapstad.

Odendaal, B.J., 1957, Die kerklike betrekkinge tussen Suid-Afrika en Nederland (1652 1952), T. Wever, Franeker.

Oosthuizen, J.L., 2008, 'Guido de Brés', in F. Gaum (red.), Christelike Kernensiklopedie, pp. 209-210, Lux Verbi, Wellington.

Polman, A.D.R., s.a., Onze Nederlandsche Geloofsbelijdenis I, Wever, Franeker.

Polman, A.D.R., s.a., Onze Nederlandsche Geloofsbelijdenis IV, Wever, Franeker.

Pont, A.D., 1981, Die historiese agtergronde van ons kerklike reg I (Dordtse Kerkorde 1619 - DKO1619), HAUM, Pretoria.

Rautenbach, I.M. \& Malherbe, E.F.J., 1994, What does the constitution say?, Rand Afrikaans University, Auckland Park.
Schippers, R., 1959, Johannes Calvijn, Kok, Kampen.

Schulze, L.F., 1978, Geloof deur die eeue, NG Kerkboekhandel, Pretoria.

Sizoo, A., s.a., Johannes Calvijn Institutie IV, Meinema, Delft.

Spoelstra, B., 1963, Die 'Doppers' in Suid-Afrika 1760-1899, Nasionale Boekhandel, Kaapstad.

Strauss, P.J., 1993, Op die tweesprong?, Universiteit van die Oranje-Vrystaat, Bloemfontein.

Strauss, P.J., 1994, 'Die Algemene Sinode van 1966 van die Ned Geref Kerk en apartheid', Studiae Historiae Ecclesiasticae 20(2), 195-214.

Strauss, P.J., 2001, 'Church and state and apartheid in South Africa. A perspective on the Dutch Reformed Church (1962-1998)', European Journal for Church and State Research 8, 327-346. https://doi.org/10.2143/EJCS.8.0.505032

Strauss, P.J., 2008, 'Abraham Kuyper (1837-1920)', in F. Gaum (red.), Christelike Kernensiklopedie, p. 634, Lux Verbi, Wellington.

Strauss, P.J., 2010, Kerk en orde vandag. Met die klem op die N.G. Kerk, Sunmedia, Bloemfontein

Strauss, S.A., 2008a, 'Dordtse Leerreëls', in F. Gaum (red.), Christelike kernensiklopedie, p. 250, Lux Verbi, Wellington.

Strauss, S.A., 2008b, 'Heidelbergse Kategismus', in F. Gaum (red.), Christelike Kernensiklopede, pp. 436-437, Lux Verbi, Wellington.

Strauss, S.A., 2008c, 'Nederlandse Geloofsbelydenis', in F. Gaum (red.), Christelike Kernensiklopedie, p. 789, Lux Verbi, Wellington.

Treurnicht, A.P., 1961, 'Grense tussen kerk en staat', in H.B. Thom (red.), Grense, pp. 37-50, Universiteitsuitgewers, Stellenbosch.

Van der Linde, G.P.L., 1983, Die Kerkorde, TG van Wyk, Pretoria.

Van Niekerk, A., 1987, 'Staatsgesag en burgerlike ongehoorsaamheid', in D.A. Du Toit (ed.), Staatsgesag en burgerlike ongehoorsaamheid, pp. 7-19, Lux Verbi, Kaapstad.

Visser, J., 1999, Die Kerkorde in praktyk, EFJS Drukkers, Orkney.

Vorster, J.D., 1960, 'Die Kerkorde van die NG Kerke', Ned Geref Teologiese Tydskrif 1(4), $12-18$ 